\title{
Erratum to: Human factors explain the majority of MODIS- derived trends in vegetation cover in Israel: a densely populated country in the eastern Mediterranean
}

\author{
Noam Levin ${ }^{1}$
}

Published online: 5 September 2015

(c) Springer-Verlag Berlin Heidelberg 2015

\section{Erratum to: Reg Environ Change \\ DOI 10.1007/s10113-015-0848-4}

The author would like to correct the first sentence in the Study area section in the publication of the original article, it should read "The study area covered Israel, the West Bank, the Gaza Strip and the Golan Heights". Additionally, the term "Israel" refers to geographic region and not to the boundaries of the state of Israel.

The online version of the original article can be found under doi:10.1007/s10113-015-0848-4.

Noam Levin

noamlevin@mail.huji.ac.il

1 Department of Geography, Hebrew University of Jerusalem, Mt Scopus, 91905 Jerusalem, Israel 